\title{
Budaya Integritas Pada Prodi-Prodi di Fakultas Tarbiyah dan Keguruan dan Fakultas Ushuluddin dan Studi Agama UIN Mataram
}

\author{
S. Ali Jadid Al Idrus \\ s.alijadid75@gmail.com \\ Fathul Maujud \\ fathulmaujud@uinmataram.ac.id
}

\begin{abstract}
Abstrak: Perguruan tinggi tidak dapat berkembang dengan baik, bila hanya memfokuskan diri pada pengajaran semata dan tidak memberikan perhatian pada riset dan pengabdian masyarakat. Kenyataan ini dapat dilihat dari lulusan perguruan tinggi yang belum banyak memenuhi standar akademik yang baik, lulusan perguruan tinggi sangat terbatas penguasaan bidang ilmu yang ditekuni, profesionalisme yang rendah, dan kesadaran riset yang terbatas, telah menyebabkan mereka tidak aplicabel dan marketable. Dominasi dharma pendidikan dan pengajaran, mengecilnya riset dan pengabdian masyarakat telah menyebabkan lulusan perguruan tinggi hanya melakukan transfer pengetahuan (transfer of knowledge), sehingga kesadaran riset dan pengabdian kepada masyarakat semakin rendah. Tujuan penelitian ini adalah untuk mengetahui dan menganalisis budaya integritas di Prodi-Prodi di Fakultas Tarbiyah dan Keguruan Dan Fakultas Ushuluddin dan Studi Agama UIN Mataram. Penelitian ini menggunakan metode kualitatif dengan tehnik wawancara, observasi, dan dokumentasi. Hasil penelitian ini menunjukkan bahwa budaya integritas di kedua fakultas tersebut tercermin pada: (a) keselarasan antara hati, pikiran, perkataan, dan perbuatan yang baik dan benar, (b) tekad dan kemauan untuk berbuat yang baik dan benar, (c) berpikir positif, arif, dan bijaksana dalam melaksanakan tugas dan fungsi, dan (d) mematuhi peraturan perundang-undangan, serta menolak korupsi, suap atau gratifikasi.
\end{abstract}

Kata Kunci: Budaya Integritas

\section{Pendahuluan}

Pendidikan tinggi di Indonesia mengalami perubahan paradigma yang cukup signifikan. Perubahan paradigma meliputi pengelolaan persaingan yang terpicu oleh perkembangan lingkungan eksternal yang sangat dinamis, perkembangan teknologi informasi, sehingga e-learning university dan sejenisnya mulai banyak dibicarakan dan 
diusahakan. ${ }^{1}$

Peningkatan kualitas sumber daya manusia Indonesia seutuhnya harus diwujudkan melalui proses transformasi pengetahuan yang dikelola secara efektif dan akuntabel oleh lembaga pendidikan baik negeri maupun sewasta. Dalam rangka meningkatkan kualitas pola pengelolaan lembaga pendidikan tersebut maka secara operasional semua elemen yang ada dalam lembaga pendidikan harus benar-benar memiliki komitmen untuk mewujudkan suasana pembelajaran yang aktif dan menyenangkan. Kondisi tersebut harus ditopang oleh paradigma berfikir tenaga pendidik yang berusaha eksis setiap harinya guna meningkatkan kualitas peserta didik yang dibinanya. Hal ini disebabkan oleh tanggungjawab yang diemban oleh setiap pendidik bukan hanya sebagai orang yang memindahkan pengetahuannya kepada peserta didik. Tenaga pendidik harus mampu menjadi fasilitator baik dalam pembentukan karakter maupun peningkatan daya kognitif peserta didik. Hal ini sesuai dengan pendapat yang diutarakan oleh Trianto yang mengatakan bahwa

Pendidikan tinggi memasuki millennium ke tiga tidak terlepas dari analisis mengenai dimensi lokal dan kemudian sejalan dengan itu mengembangkan dimensi globalnya, maka pengembangan pendidikan tinggi memasuki era globalisasi memiliki dua dimensi yang erat berkaitan yaitu lokalisme dan globalisme. Menurut pandangan Tilaar, pada dimensi lokal visi pendidikan tinggi kita mempunyai unsur-unsur sebagai berikut; (1) akuntabilitas, (2) relevansi, (3) kualitas, (4) otonomi kelembagaan, dan (5) jaringan kerja sama. Pada dimensi global visi tersebut mempunyai tiga aspek yaitu; (1) kompetitif, (2) kualitas, dan (3) jaringan kerja sama. ${ }^{2}$

Perguruan tinggi tidak dapat berkembang dengan baik, bila hanya memfokuskan diri pada pengajaran semata dan tidak memberikan perhatian pada riset dan pengabdian masyarakat. Kenyataan ini dapat dilihat dari lulusan perguruan tinggi yang: (1) belum banyak memenuhi standar akademik yang baik, sebagai layaknya lulusan perguruan tinggi pada umumnya, (2) Lulusan perguruan tinggi sangat terbatas penguasaan bidang ilmu yang ditekuni, (3) profesionalisme yang rendah, dan kesadaran riset yang terbatas, telah menyebabkan mereka tidak aplicabel dan marketable. Dominasi dharma pendidikan dan pengajaran, mengecilnya riset dan

${ }^{1}$ E. A. Koncoro. Leadership ... (PT. Alfabeta Bandung: 2009), 100.

${ }^{2}$ H. A. R. Tilaar, Paradigma baru Pendidikan nasional, (Jakarta: Rineka cipta, 2000), 110. 
pengabdian masyarakat telah menyebabkan lulusan perguruan tinggi hanya melakukan transfer pengetahuan (transfer of knowledge), sehingga kesadaran riset dan pengabdian kepada masyarakat semakin rendah. ${ }^{3}$

Tabel.1

Dinamika perubahan kelembagaan UIN Mataram ${ }^{4}$

\begin{tabular}{|c|c|c|}
\hline Tahapan & Bentuk Kelembagaan & Dasar Hukum \\
\hline Tahap I & $\begin{array}{l}\text { Sekolah Persiapan IAIN (SP- } \\
\text { IAIN) cabang Al-Jami'ah } \\
\text { Yogyakarta }\end{array}$ & $\begin{array}{l}\text { SK Menteri Agama No } 93 \\
\text { tahun } \\
1963 \text { tgl } 16 \text { September } 1963\end{array}$ \\
\hline Tahap II & $\begin{array}{l}\text { Pembukaan Fakultas } \\
\text { Tarbiyah IAIN Sunan Ampel } \\
\text { Cabang Mataram }\end{array}$ & $\begin{array}{l}\text { SK Menteri Agama No. } 63 \\
\text { Tahun } \\
1966 \text { tgl } 24 \text { Oktober } 1966\end{array}$ \\
\hline Tahap III & $\begin{array}{l}\text { Program Doktoral (Sarjana } \\
\text { Lengkap) }\end{array}$ & $\begin{array}{l}\text { SK Dirjen Bimbaga Islam } \\
\text { Departemen Agama dengan } \\
\text { Surat } \\
\text { No. F/x/1748, tgl } 06 \text { Mei } 1982\end{array}$ \\
\hline Tahap IV & $\begin{array}{l}\text { Fakultas Syariah IAIN Sunan } \\
\text { Ampel di Mataram }\end{array}$ & $\begin{array}{l}\text { SK Menteri Agama RI, Nomor } \\
27 / 1994\end{array}$ \\
\hline Tahap V & STAIN Mataram & $\begin{array}{l}\text { KEPRES RI, Nomor } 11 \text { tahun } \\
1997 .\end{array}$ \\
\hline Tahap VI & IAIN Mataram & $\begin{array}{l}\text { SK Presiden RI. No. } 91 \text { Tahun } \\
\text { 2004, tgl } 18 \text { Oktober } 2004\end{array}$ \\
\hline TahapVI & UIN Mataram & $\begin{array}{l}\text { KERPRES RI No. } 34 \text { Tahun } \\
2017\end{array}$ \\
\hline
\end{tabular}

Secara tidak sadar, tiap-tiap orang di dalam suatu lembaga/ perusahaan

${ }^{3}$ Syahrizal Abbas, Manajemen Perguruan Tinggi, 2.

${ }^{4}$ Dokumentasi naskah akademik penataan unit organisasi dari IAIN menuju UIN Mataram, tanggal 16 Mei 2018. 
mempelajari budaya yang berlaku di dalam lembaga/ perusahaan tersebut. Apalagi bila ia sebagai orang baru supaya dapat diterima oleh lingkungan tempat kerja, ia berusaha mempelajari apa yang dilarang dan apa yang diwajibkan, apa yang baik dan apa yang buruk, apa yang benar dan apa yang salah, dan apa yang harus dilakukan dan apa yang tidak boleh dilakukan di dalam lembaga/ perusahaan tempat bekerja itu.

Budaya kerja dapat difungsikan sebagai tuntutan yang mengikat para anggotanya, maka individu yang ada dalam lembaga/ perusahaan secara tidak langsung akan terikat sehingga dapat membentuk sikap dan perilaku dengan visi misi lembaga/ perusahaan. Proses tersebut akan membentuk individu yang bagus, integritas tinggi yang nantinya akan menghasilkan SDM yang berkualitas.

Budaya kerja Kementrian Agama merupakan seperangkat prinsip-prinsip yang harus dijadikan acuan dalam bekerja bagi semua komponen di lingkup Kementrian Agama sehingga kualitas kerja dapat terbangun dan dapat terwujdnya sinergi yang baik. ${ }^{5}$ Perilaku semua komponen baik struktural maupun non struktural harus mampu menjabarkan masing-masing item perangkat budaya kerja Kementrian Agama dalam setiap pekerjaan yang dilakukan. Tiap komponen, harus memiliki motivasi kerja yang mengacu pada terbangunnya kualitas kerja.

\section{Bertekad dan berkemauan untuk berbuat yang baik dan benar}

Berdasarkan hasil wawancara tanggal 27 Juni 2018 dengan sekretaris jurusan PBA tentang integritas dosen dan staf di jurusan Pendidikan Bahasa Arab adalah dosen memiliki tekad dan kemauan untuk mengajar dan membimbing mahasiswa. ${ }^{6}$ Dimana tekad itu sumber dari segalanya yang harus dipupuk dari sejak dini oleh selaku dosen dan staf. Karena tekad itulah yang menjadikan seseorang menjadi bersungguh-sungguh dalam menjalankan tugasnya.

Kemauan adalah sebuah keinginan atau keihlasan dalam menjalankan amanah yang diberikan tanpa mengutamakan reward atau tanpa harus diprintah untuk melaksanakan tugasnya. Dengan adanya kemauan akan membentuk sebuah ide-ide baru yang akan muncul dalam menjalankan tugasnya. Sehingga lembaga akan menjadi maju dan mampu berkompetisi dengan yang lainnya, baik tingkat nasional maupun

${ }^{5}$ Anhar, Budaya Kerja Kementrian Agama, (Jakarta: Kementrian Agama RI, 2015), 15

${ }^{6}$ Wawancara, Nurman, M.Pd, Tanggal 27 Juni 2018 
internasional.

Berdasarkan wawancara tersebut, tekad dan kemauan para dosen dan staf untuk mengajar dan membimbing mahasiswa akan membentuk sebuah budaya. Budaya tersebut dinamakan budaya Integritas antara dosen dengan staf dalam mengajar dan membimbing mahasiswa.

Kemauan dan tekad para dosen dan staf yang ada di FTK dan FUSA harus dipertahankan, karena dengan hal tersebut segala kegiatan yang ada ataupun aktivitas yang akan dilakukan akan berjalan dengan lancar dan penuh dengan Inovatif. Inovasiinovasi baru ini yang sangat diharapkan oleh sebuah lembaga. Sehingga dari harikehari atau dari bulan kebulan dan dari tahun ke tahun akan ada perubahan yang signifikan di fakultas tersebut. Dengan tekad dan kemauan tersebut sudah terbentuk maka para dsosen dan staf FTK dan FUSA secara umum tidak ada yang melanggar tata tertib yang sudah dibuat atau yang sudah disepakati bersama.

"Selama ini kami tidak pernah membuat dan menulis visi misi secara sfesifik. Visi misi telah dirumuskan, namun karena terkait dengan kondisi dan kendala pada saat itu sehingga visi dan misi tidak terdokumentasikan. Namun jika kita mencermati apa yang sering disampaikan oleh pimpinan bahwa tujuan bekerja adalah untuk menciptakan masyarakat secara umum dan mahasiswa secara khusus menjadi manusia yang beriman dan bertaqwa kepada Allah swt. dengan menjalankan perintahnya dan menjauhi segala larangannya".?

Dalam rangka ikut serta mencerdaskan kehidupan bangsa yang didasari dengan niat yang tulus serta dukungan dari masyarakat yang peduli terhadap kualitas pendidikan/pengajaran di lingkungan kampus, Perencanaan pengembangan pendidikan tinggi, tidak bisa terlepas dari cita-cita dan harapan masyarakat dalam mengembangkan kampus, serta al-Qur'an dan al-Hadist yang dijadikan sebagai sumber nilai perjuangan dan kehidupan tetapi juga sebagai sumber inspirasi, prinsip dan komitmen yang akhirnya melahirkan tradisi. ${ }^{8}$

${ }^{7}$ KBG FTK. Wawancara, 16 Juli 2018.

${ }^{8}$ PMP FTK Wawancara, 16 Juli 2018. 


\section{Berpikir positif, arif, dan bijaksana dalam melaksanakan tugas dan fungsi}

Sedangkan pada tanggal 20 Juli 2018 dilakukan wawancara dengan ketua jurusan Tadris Kimia tentang integritas dosen, data yang diproleh sama dengan hasil wawancara dengan sekretaris jurusan PBA yaitu para dosen memiliki tekad dan kemauaan, berfikir positif, arif, dan bijaksana dalam melaksanakan tugas dan fungsi.

Berfikir positif atau istilah agama "Husnuzzan" merupakan sesuatu yang sulit untuk diaplikasikan oleh seseorang. Akan tetapi para dosen dan staf di FTK dan FUSA selalu berfikir positif dalam bekerjasama baik antar dosen maupun staf. Dengan hal tersebut maka kenyamanan dalam menjalankan tugas dan fungsinya sebagai dosen maupun staf terbentuk. Dan para dosen dan staf merasa betah di FTK dan FUSA, sehingga kelihatan kompak dalam bekerja.

Sedangkan arif artinya pandai, cerdik, berilmu. Dosen dan staf di FTK dan FUSA telah memiliki ilmu atau kompeten di bidangnya masing-masing. Sehingga dalam menjalankan tugas dan fungsinya para dosen dan staf bertanggungjawab terhadap tugasnya. Kearifan tersebut selalu dijaga, terutama para dosen mengajar sesuai dengan bidang keahliannya masing-masing. Begitu juga pada para stafnya bekerja sesuai dengan bidangnya masing-masing.

Adapun kebijaksanaan para dosen dan staf di FTK dan FUSA dalam menjalankan tugas dan fungsinya, berdasarkan hasil wawancara secara umum sudah terealisasi. Hal tersebut dapat dibuktikan dengan kesabaran para dosen menghajar dan membimbing para mahasiswa, begitu juga dengan para staf yang selalu bersabar melayani para mahasiswa. Jika hal tersebut selalu dilakukan maka tata tertib akan terbentuk dan lancar dengan baik.

Dapat disimpulkan bahwa berfikir positif, arif dan bijaksana dalam melaksanakan tugas dan fungsinya merupakan salah satu budaya integritas yang harus dan selalu ditumbuh kembangkan demi keberlanjutan sebuah lembaga, khususnya UIN Mataram.

${ }^{9}$ Wawancara, Kajur Tadris Kimia, 20 Juli 2018 


\section{Mematuhi peraturan perundang-undangan}

Begitu juga dengan hasil wawancara dengan salah satu dosen PBA, yaitu Drs. H. L. Ahmad Busyairi, MA., yang mengatakan hal yang sama tentang para dosen dan staf yang ada di Fakultas Tarbiyah dan Keguruan dan Fakultas Ushuluddin dan Studi Agama UIN Mataram, bahwa para dosen dan staf senantiasa membimbing mahasiswa dengan ramah, dan mengajar mahasiswa dengan efektif dan efisien, serta adanya keinginan untuk mengembangkan lembaga pada umumnya, dan mematuhi peraturan dan perundang-undangan. ${ }^{10}$

Hal tersebut dibuktikan dengan taatnya para dosen dalam mengajar sesuai jadwal ngajar yang sudah ditentukan dalam kalender akademik UIN Mataram. begitu juga para stafnya selalu taat dalam memenuhi kebutuhan para dosen dan mahasiswa tanpa menunggu komfirmasi terlebih dahulu.

Sebuah paradigma dapat berubah, bergeser dan berkembang sesuai dengan kebutuhan. Jadi, sebuah paradigma tidak mesti harus statis, tetapi sebaliknya bias dan harus bersifat dinamis; apalagi paradigm pendidikan, yang terkait dengan berbagai aspek kehidupan masyarakat, yang senantiasa berubah dan berkembang, khususnya dalam konteks globalisasi. Pergeseran paradigma terjadi melalui dua cara. Pertama, secara inside out, yakni dilakukan secara sadar, sukarela, dan bahkan secara proaktifantisipatif. Dalam konteks ini, perubahan paradigma dapat terjadi melalui pembelajaran, pendidikan, perluasan wawasan, peniruan, pengenalan lebih intens atas kemampuan diri, peningkatan pengalaman, dan sebagainya. Dengan cara-cara seperti ini, paradigma seseorang menjadi berkembang (paradigm paralysis). Kedua, secara outside in, atau secara terpaksa dan reaktif, karena adanya peristiwa 'yang memaksa' dan bahkan dapat menimbulkan dampak traumatis. Hasilnya, seseorang mengubah atau menggeser paradigmanya agar dapat terhindar dar berbagai bentuk abnormalitas dan deviasi lainnya.

Perguruan tinggi Islam tidak dapat berkembang dengan baik, bila hanya memfokuskan diri pada pengajaran semata dan tidak memberikan perhatian pada riset dan pengabdian masyarakat. Problema manajemen perguruan tinggi, telah menjadi isu utama rehabilitasi dan rekonstruksi dunia pendidikan tinggi. Penerapan

${ }^{10}$ Wawancara, Drs. H. L. Ahmad Busyairi, MA., Tanggal 16 Agustus 2018 
manajemen perguruan tinggi selama ini, belum banyak membawa dampak signifikan bagi perwujudan tri dharma perguruan tinggi yang bermutu. kenyataan ini dapat dilihat dari lulusan perguruan tinggi di yang: (1) belum banyak memenuhi standar akademik yang baik, sebagai layaknya lulusan perguruan tinggi pada umumnya, (2) Lulusan perguruan tinggi sangat terbatas penguasaan bidang ilmu yang ditekunimya, (3) profesionalisme yang rendah, dan kesadaran riset yang terbatas, telah menyebabkan mereka tidak aplicabel dan marketable. Dominasi dharma pendidikan dan pengajaran, mengecilnya riset dan pengabdian masyarakat telah menyebabkan lulusan perguruan tinggi hanya melakukan transfer pengetahuan (transfer of knowledge), sehingga kesadaran riset dan pengabdian kepada masyarakat semakin rendah.

\section{Menolak Korupsi, Suap atau Gratifikasi}

Menolak korupsi, suap atau gratifikasi adalah hal yang sangat dijauhi oleh para dosen dan staf FTK dan FUSA, hal tersebut dibuktikan dengan tidak adanya temuan-temuan baik dosen maupun staf dalam memungut pungutan liar di mahasiswa atau di kegiatan-kegiatan lainnya.

Berdasarkan hasil wawancara dengan Wakil Dekan 1 Fakultas Tarbiyah dan Keguruan, bahwa korupsi, suap atau gratifikasi adalah hal yang tercela dan menjatuhkan nama baik seseorang jika melakukan hal tersebut. Sungguh tidak elok jika hal tersebut terjadi di kalangan dosen atau staf FTK dan FUSA, karena tidak bisa dijadikan suri teladan yang baik di kalangan mahasiswa. Sedangkan dosen adalah sebaik-baik teladan, dan staf adalah sebaik-baik pelayan bagi mahasiswanya. ${ }^{11}$

Berdasarkan hasil wawancara teresbut dapat disimpulkan bahwa budaya integritas pada prodi-prodi di Fakultas Tarbiyah dan Keguruan Dan Fakultas Ushuluddin dan Studi Agama UIN Mataram sudah lama terbentuk dengan baik, sehingga dalam rutinitas kerja lebih mudah baik dalam komunikasi maupun dalam aplikasi kerja. Sehingga lambat laun lembaga UIN Mataram akan menjadi lembaga yang Go Internasional, jika budaya integritas tetap dikembangkan di kalangan para dosen maupun staf.

Oleh karena itu, dengan tekad bersama, keinginan bersama untuk

11 Wawancara dengan Abdul Quddus, tanggal 4 Juli 2018. 
membimbing dan melayani mahasiswa dengan aktif, kreatif dan yang lebih utama dengan kelembutan dan keremahan, serta menolak korupsi, suap atau gratifikasi adalah sebuah modal utama terbentuknya budaya integritas, tidak hanya dikalangan dosen dan staf, tapi dikalangan antar fakultas maupun lembaga UIN Mataram pada umumnya.

Menurut Gering Supriyadi dan Tri Guno, budaya kerja merupakan suatu falsafah yang didasari oleh pandangan hidup sebagai nilai-nilai yang menjadi sifat, kebiasaan dan kekuatan pendorong, membudaya dalam kehidupan suatu kelompok masyarakat atau organisasi, kemudian tercermin dari sikap menjadi perilaku, kepercayaan, cita-cita, pendapat dan tindakan yang terwujud sebagai "kerja" atau "bekerja". Budaya Kerja organisasi adalah manajemen yang meliputi pengembangan, perencanaan, produksi dan pelayanan suatu produk yang berkualitas dalam arti optimal, ekonomi dan memuaskan. ${ }^{12}$

Wahana Budaya Kerja adalah produktivitas, yang berupa perilaku kerja yang yang tercemin antara lain: kerja keras, ulet, disiplin, produktif, tanggung jawab, motivasi, manfaat, kreatif, dinamik, konsekuen, konsisten, responsif, mandiri, makin lebih baik dan lain-lain. Budaya kerja Kementrian Agama merupakan seperangkat prinsip-prinsip yang harus dijadikan acuan dalam bekerja bagi semua komponen di lingkup Kementrian Agama sehingga kualitas kerja dapat terbangun dan dapat terwujdnya sinergi yang baik. ${ }^{13}$ Menurut Budhi Paramita dalam tulisannya berjudul "Masalah Keserasian Budaya dan Manajemen di Indonesia", budaya kerja dapat dibagi menjadi:

a. Sikap terhadap pekerjaan, yakni kesukaan akan kerja dibandingkan dengan kegiatan lain, seperti bersantai, atau semata-mata memperoleh kepuasan dari kesibukan pekerjaannya sendiri, atau merasa terpaksa melakukan sesuatu hanya untuk kelangsungan hidupnya.

b. Perilaku pada waktu bekerja, seperti rajin, berdedikasi, bertanggungjawab, berhati-hati, teliti, cermat, kemauan yang kuat untuk mempelajari tugas dan

12 Gering Supriyadi dan Tri Guno, Budaya Kerja Organisasi Pemerintah, Jakarta: Lembaga Administrasi Negara, 2003), 8.

13 Anhar, Budaya Kerja Kementrian Agama (Jakarta: Kementrian Agama RI, 2015), 15 
kewajibannya, suka membantu sesama karyawan, atau sebaliknya. ${ }^{14}$

Budaya kerja di Kantor Kementerian Agama memiliki lima prinsip budaya kerja, yaitu:

1) Integritas

Merupakan keselarasan antara hati, pikiran, perkataan, dan perbuatan yang baik dan benar. Beda dengan makhluk lainnya, kalau kehilangan integritas maka tidak ada bedanya dengan makhluk lain. Identitas kita ada dalam integritas tersebut. Orang yang mempunyai integritas pribadi yang baik adalah orang yang tidak diragukan lagi serta selalu konsisten dalam kata dan perbuatan.

2) Profesionalitas

Merupakan bekerja secara disiplin, kompeten, dan tepat waktu dengan hasil terbaik. Orang yang menguasai tidak sekedar mampu dan mengetahui tapi menguasai di bidangnya, dan ke arah mana, implikasi, konsekwensi yang muncul, kita memahami betul. Orang yang terampil, andal dan sangat bertanggung jawab dalam menjalankan profesinya. Orang yang mempunyai integritas biasanya juga profesional. Profesionalitas pada intinya kompetensi untuk melakukan tugas dan fungsinya secara bertanggung jawab.

3) Inovasi

Merupakan yang sudah ada dan mengkreasikan hal baru yang lebih baik. Diantara beberapa problem kita dalam birokrasi, selalu terbelenggu dalam rutinitasnya, yang dia lakukakn hari ini, besok melakukan yang sama, begitulah setiap harinya. Ia menandaskan bahwa perubahan masyarakat sangat dinamis, maka ironi kalau kita di dalamnya statis. Tuntutan di masyarakat dinamis kita, maka harus muncul dengan kreasi, bagaimana menjalankan fungsi pelayanan dan pembinaan.

4) Tanggung jawab

Merupakan bekerja secara tuntas dan konsekuen. Sebagai manusia, kita harus mempunyai kesadaran bahwa apa yang dilakukan ada tanggung jawab pada manusia dan Tuhan. Kementerian minta kesadaran harus given.

${ }^{14}$ Rusdiana dan yeti Hermayati, Pendidikan Profesi Keguruan,(Bandung : Pustaka Setia, 2015, 68 
Menurutnya, sudah terlalu banyak pengalaman rekan sejawat yang bermasalah dengan hukum, ini setidaknya sudah lebih dari cukup, setidaknya jangan menambah deretan panjang kasus yang serupa. Kesediaan menanggung sesuatu, bila salah wajib memperbaiki atau dapat dituntut dan diperkarakan.

5) Keteladanan

Yakni menjadi contoh yang baik bagi orang lain. Kementerian minta untuk menanamkan dalam diri Aparatur Sipil Negara (ASN) Kementerian Agama, karena persepsi publik bahwa kita mengerti agama. Kementerian Agama berpesan, untuk menjaga ucapan, perilaku dan tindakan karena dilihat publik. Sikap perilaku yang dinyatakan secara sadar maupun tidak disadari dari seorang pemimpin yang dipersepsi oleh bawahannya sebagai sesuatu yang memicu atau mendorong bawahanya untuk mencontohnya. ${ }^{15}$

Melaksanakan budaya kerja mempunyai arti yang sangat dalam, karena akan merubah sikap dan perilaku Sumber Daya Manusia untuk mencapai produktivitas kerja yang lebih tinggi dalam menghadapi tantangan masa depan. Manfaat yang didapat antara lain sebagai berikut:

1. Menjamin hasil kerja dengan kualitas yang lebih baik.

2. Membuka seluruh jaringan komunikasi, keterbukaan, kebersamaan, kegotong-royongan, kekeluargaan, menemukan kesalahan dan cepat memperbaiki.

3. Cepat menyesuaikan diri perkembangan dari luar (faktor eksternal seperti pelanggan, teknologi, sosial, ekonomi, dan lain-lain).

4. Mengurangi laporan berupa data-data dan informasi yang salah dan palsu.16

Selain itu masih banyak lagi manfaat yang muncul seperti kepuasan kerja meningkat, pergaulan yang lebih akrab, disiplin meningkat, pengawasan fungsional berkurang, pemborosan berkurang, tingkat absensi turun, ingin belajar terus, ingin memberikan yang terbaik bagi organisasi dan lain-lain.

Pendidikan merupakan kerangka acuan untuk melihat kualitas sumber daya manusia dalam setiap negara. Indonesia termasuk salah satu negara berkembang

15 Kemenag, Pedoman Budaya Kerja, (Jakarta: Kemenag, 2015), 14

16 Supriadi Dedi, Kreativitas, kebudayaan, dan Perkembangan Iptek. Alfabeta: Bandung, 2009), 76. 
yang sedang gencar melakukan perubahan kearah yang lebih baik. Dalam rangka menunjang hal tersebut maka upaya perbaikan terhadap kualitas pendidikan terus dilakukan dengan memperbaiki sistem pendidikannya melalui Undang-Undang Republik Indonesia Nomor 20 Tahun 2003 Pasal 3 yang menyatakan bahwa tujuan dari Pendidikan Nasional adalah membentuk manusia Indonesia seutuhnya.

Pendidikan Nasional berfungsi mengembangkan kemampuan dan membentuk watak serta peradaban bangsa yang bermartabat dalam rangka mencerdaskan kehidupan bangsa, bertujuan untuk berkembangnya potensi peserta didik agar menjadi manusia yang beriman dan bertakwa kepada Tuhan Yang Maha Esa, berakhlak mulia, sehat, berilmu, cakap, kreatif, mandiri, dan menjadi warga negara yang demokratis serta bertanggung jawab.17 Melalui penanaman karakter yang mulia yang dilandasi oleh iman dan takwa akan mampu melahirkan kemampuan intelektual.

\section{Budaya profesionalitas pada Prodi-Prodi di Fakultas Tarbiyah dan} Keguruan Dan Fakultas Ushuluddin dan Studi Agama UIN Mataram

\section{a. Melakukan pekerjaan sesuai kompetensi jabatan}

Implementasi strategi pengembangan pendidikan tinggi dapat ditunjukkan melalui fenomena individu maupun sosial didasarkan pada premis nilai dan fakta, menyimpulkan sebuah pilihan diantara alternatif, dengan maksud bergerak menuju satu situasi yang diinginkan dan UIN mataram sudah menerapkan manajemen modern karena melibatkan stakeholdernya, nilai positif dalam penerapan strategi pengembangan pendidikan tinggi mempertimbangkan aspek yang perlu dipertimbangkan yaitu faktor agama, kebangsaan dan kemasyarakatan, atau tepatnya pemahaman keagamaan, sebagaimana hasil wawancara dengan berikut ini:

Pengambilan keputusan yang berkaitan dengan apapun, selalu menggunakan musyawarah sebagai media yang selalu digunakan pada setiap kali menentukan kebijakan yang ada. Pengambilan keputusan sebagai proses seleksi dari suatu kegiatan atau posisi dari sejumlah alternatif yang tersedia, sehingga memerlukan media yang tepat agar efektif. ${ }^{18}$

${ }^{17}$ Syaiful Bahri Djamarah, Strategi Belajar Mengajar (Jakarta: Rineka Cipta, 2009), 27.

18 PMP FTK Wawancara, 16 Juli 2018. 
Data ini memberikan gambaran bahwa pekerjaan yang dilakukan oleh para dosen dan staf diberikan sesuai dengan kapasitas dan kompetensi yang dimiliki. Para dosen mengajar sesuai dengan bidang keahlian mereka, dan para staf diberikan tugas sesuai dengan kemampuan yang mereka miliki.

\section{b. Disiplin dan Bersungguh-Sungguh dalam Bekerja}

Aktual dan faktual tentang fenomena organisasi yang terjadi saat ini dapat disaksikan serta dinyatakan bahwa sudah terjadi pergeseran paradigma maupun opersasional dalam industri pendidikan yang mengakibatkan kesenjangan antara tuntutan dan harapan. Strategi yang dikembangkan dalam dunia pendidikan adalah institusi jasa yakni memberikan pelayanan (service) sesuai dengan yang diinginkan oleh pelanggan. Dengan demikian organisasi yang tidak memiliki manajemen strategic dapat memaksa organisasi pendidikan pada situasi dan kondisi mengurangi atau menghentikan operasi organisasi.

Di dalam institusi UIN Mataram dimana ada FTK dan FUSA, Perguruan tinggi Islam sebagai bagian dari satuan pendidikan dituntut untuk senantiasa merevitalisasi strateginya guna menjamin kesesuain tututan lingkungan dan persaingan dengan kekuatan internal yang dimilikinya. Ini penting mengingat ketidakmampuan suatu satuan pendidikan dalam merespons peluang dan ancaman eksternal akan mengakibatkan menurunnya daya saing dan atau terhambatnya pencapaian kinerja satuan pendidikan itu. Jika hal ini dibiarkan maka akan mengancam kelangsungan satuan pendidikan yang bersangkutan.

Meningkatkan daya saing dan mutu perguruan tinggi, maka perlu diupayakan adanya indicator kinerja perguruan tinggi, yang untuk sementara dapat dinyatakan dalam: (1) kuantitas dan kualitas serta relevansi lulusan, (2) kuantitas dan kualitas serta relevansi hasil penelitian dan pengembangan, (3) kuantitas dan kualitas dan relevansi kegiatan pengabdian pada masyarakat.

Berdasarkan wawancara dengan Wakil Dekan I Fakultas Ushuluddin Dan Studi Agama (FUSA), ditemukan bahwa pendidikan Tinggi Islam ke depan secara umum harus mentransformasi nilai-nilai sains, teknologi, seni, masyarakat, lingkungan, berupa: (1) unifikasi; (2) konkretisasi, dan (3) obyektivikasi, sehingga institusi mampu tampil secara kreatif dalam mendialogkan kebudayaan lokal dan 
budaya baru dan isu-isu baru yang muncul sebagai bagian dari dinamika perguruan tinggi. Hal itu dilakukan agar dapat memenangkan persaingan, kompetensi yang dan mampu memberikan kontribusi yang penting dan besar terhadap nilai-nilai yang dibutuhkan masyarakat. ${ }^{19}$

Oleh karena itu pengelola di FUSA memiliki kepekaan untuk menetapkan nilainilai yang diharapkan oleh konsumen atau masyarakat pada jasa yang diberikan, apa yang sebenarnya dibayar oleh konsumen, apa sebab konsumen mau membayar lebih pada jasa yang diberikan dan nilai manakah yang menjadi komponen terpenting bagi konsumen sehingga mereka mau membayar lebih. Kompetensi itu harus unik dan bermutu, tidak dapat ditiru dengan mudah oleh para pesaing dan para konsumen memberikan nilai tinggi pada kompetensi yang dimiliki oleh perguruan tinggi.

\section{c. Melakukan Pekerjaan Secara Terukur}

Sementara itu, secara eksternal Pendidikan Tinggi Islam dihadapkan pada dua problem mendasar yaitu: pertama, krisis etika dan moral anak bangsa. Etika dan tatakrama yang telah terinternalisasi sejak lama dalam kehidupan sosial dan budaya anak bangsa yang santun terdegradasi, berubah menjadi gugusan retorika yang tak bermakna. Bangsa Indonesia yang dikenal sebagai bangsa yang mencerminkan tipikal qur'ani (berkarakter sesuai dengan ajaran Qur'an) karena indahnya kehidupan di tengah kondisi bangsa yang serba plural, menjadi bangsa pemangsa sesama (kanibal) yang mengerikan. Kedua, tantangan masyarakat dunia, dimana era globalisasi hari ini ditandai dengan berbagai kata kunci seperti: kompetisi, transparansi, efisiensi, kualitas, dan profesionalitas serta kecenderungan baru masyarakat global pada wacana dan praktik demokrasi.

Dari hasil wawancara dengan Wakil Dekan II Fakultas Tarbiyah dan Keguruan, ditemukan bahwa dewasa ini dalam dunia pendidikan, khususnya Pendidikan Tinggi Islam dihadapkan pada tuntutan masyarakat yang menghendaki agar Pendidikan Tinggi mampu menghasilkan output (lulusan) yang benar-benar berkualitas tinggi sehingga mampu bersaing di tengah era yang kompetitif ini. Lulusan yang mereka harapkan adalah lulusan yang menguasai ilmu pengetahuan dan

${ }^{19}$ Wawancara dengan Abdul Fattah, tanggal 26 Juli 2018. 
teknologi (iptek), keahlian, dan keterampilan yang dibutuhkan untuk mencapai suatu kehidupan yang layak dan sejahtera di dunia. Dan yang tidak kalah pentingnya juga yaitu memiliki bekal ilmu pengetahuan agama yang kokoh sebagai pondasi dalam kehidupan, sehingga menjadikannya pribadi yang senantiasa menjunjung tinggi etika, moral, akhlak mulia, serta amal shalih. Keseimbangan antara penguasaan ilmu pengetahuan dengan penanaman keimanan dan ketaqwaan (Imtaq) adalah suatu keniscayaan yang tidak bisa ditawar lagi. ${ }^{20}$

Selain yang diungkapkan di atas, saat ini sudah terjadi pergeseran orientasi dalam kehidupan manusia. Hal tersebut membuat manusia tergila-gila pada prestasi duniawi, efisiensi, dan kesenangan yang serba semu dengan melakukan pembaharuan teknologi yang tidak terkontrol dan mengakibatkan penyakit ekologi dan sosial. Oleh karena itu, sudah saatnya Pendidikan Tinggi Islam mengkonfigurasi tujuan institusionalnya dengan memperhatikan berbagai tuntutan masyarakat dan zaman yang terus berubah. Jika tidak ada, maka Pendidikan Tinggi Islam tidak pernah survive (bertahan hidup) dalam budaya dan umatnya sendiri seiring dengan pergeseran nilai yang semakin deras di era informasi ini. Untuk eksis dalam dunia yang dinamis maka sekali lagi, penguasaan dimensi profan (duniawi) yang terwakili dengan tingginya IPTEK yang dikuasai dan dimensi sakral (ukhrawn) yang terwakili oleh dalamnya tingkat iman dan taqwa adalah suatu hal yang tidak bisa ditawar lagi. Dalam hal ini, Pendidikan Tinggi Islam diharapkan mampu mencetak figur-figur ulama yang intelek profesional dan atau intelek profesional yang ulama. Atau dengan kata lain, lulusan yang diharapkan memiliki keseimbangan antara penguasaan ilmu pengetahuan dan kedalaman spiritual.

Berdasarkan penelusuran dokumen yang dimiliki oleh FTK dan FUSA, baik dokumen Renstra maupun Visi dan Misinya, terungkap bahwa Dalam usaha menjawab problematika yang telah dikemukakan di atas, kedua fakultas tersebut memiliki upaya-upaya yang bersifat strategis untuk menjadikan lembaga yang mampu bersaing dengan lembaga Perguruan Tinggi Umum lainnya. Oleh karena itu, dalam upaya untuk meraih keunggulan daya saing terhadap tuntutan masyarakat yang selalu mengalami perubahan akibat derasnya arus globalisasi, maka penerapan manajemen

${ }^{20}$ Wawancara dengan Syamsul Arifin, tanggal 10 Juli 2018. 
strategik menjadi suatu keharusan. Karena dengan menerapkan manajemen strategik sebagai suatu kerangka kerja (frame work), maka akan dapat menyelesaikan setiap persoalan strategis di dalam sebuah lembaga/perusahaan, terutama yang berkaitan dengan persaingan. ${ }^{21}$

Oleh karena itu para manajer diajak untuk berpikir lebih kreatif atau berpikir strategik. Pemecahan masalah dengan menghasilkan serta mempertimbangkan lebih banyak alternatif yang dibangun dari suatu analisa yang lebih teliti dan komprehensif akan lebih efektif sehingga menjanjikan suatu hasil yang menguntungkan.

\section{Budaya Inovasi pada Prodi-Prodi di Fakultas Tarbiyah dan Keguruan Dan Fakultas Ushuluddin dan Studi Agama UIN Mataram}

Diantara beberapa problem yang muncul dalam lembaga pendidikan tinggi adalah dalam hal birokrasi, seringkali terbelenggu dalam rutinitasnya, yang dilakukakn hari ini, seringkali diulang pada hari esoknya. Begitulah setiap harinya. Dalam kontek kekinian, perubahan masyarakat sangat dinamis, maka ironi jikalau para civitas akademik dalam lembaga pendidikan selalu statis. Tuntutan di masyarakat dinamis kita, maka harus muncul dengan kreasi, bagaimana menjalankan fungsi pelayanan dan pembinaan yang inovatif.

Menurut Wakil Dekan II Fakultas Ushuluddin Dan Studi Agama (FUSA), bahwa dalam menjalankan tugas sebagai dosen, staf dan lain sebagainya, harus ditanamkan nilai-nilai birokratik, yang meliputi memiliki kemampuan teknik, memiliki spesialisasi pada bidang keahlian, menentukan tujuan kerja, memiliki tindakan yang nyata, rasional, dan memiliki tugas yang terstruktur. ${ }^{22}$

Tenaga pendidik (dosen), kependidikan dan staf di Fakultas Tarbiyah dan Keguruan dan di Fakultas Usuluddin dan Studi Agama UIN Mataram digolongkan bervariasi, baik dari jenjang pendidikan yang dimilikinya maupun komptensi dalam mengajar dan menjalankan aktivitas perkantoran. Kondisi ini mengharuskan pihak pimpinan Fakultas untuk mengambil sikap dan keputusan untuk memberikan pelatihan-pelatihan, baik di bidang pengembangan strategi pembelajaran, media

${ }^{21}$ Dokumen Renstra dan Visi Misi, dianalisi tanggal 13 Juli 2018. 
pembelajaran, pelayanan akademik mahasiswa, dan penguatan-penguatan di bidang teknologi informasi. Program-program tersebut dilakukan agar para dosen dan staf dapat menjalankan kewajibannya secara profesional.

Upaya-upaya tersebut secara praktis dapat membantu semua pihak dalam melaksanakan tugas dan kewajibannya, sehingga pelayanan yang bermutu kepada mahasiswa memberikan kontribusi nyata bagi pengembangan dan peningkatan kualitas mahasiswa di kedua Fakultas tersebut. Kondisi diperoleh dari hasil observasi yang menunjukkan bahwa tenaga pendidik dan tenaga kependidikan yang ada di kedua Fakultas tersebut dapat bekerja memberikan pelayanan dengan baik dan inovatif sesuai dengan tuntutan perkembangan kebutuhan mahasiswa dan masyarakat. $^{23}$

Untuk meningkatkan kualitas layanan akademik dan lulusan di Perguruan Tinggi, termasuk di dalamnya UIN Mataram, maka perlu dikembangkan secara strategis kapasitas SDM terutama tenaga edukatif atau dosen. Karena pentingnya peran SDM dalam pelaksanaan dan pencapaian tujuan lembaga, maka pengelolaan sumber daya manusia harus memperhatikan beberapa aspek seperti aspek staffing, pelatihan dan pengembangan, motivasi dan pemeliharaannya yang secara lebih mendetail.

Karena mengelola SDM merupakan suatu sistem, maka beberapa aspek yang menjadi perhatian tersebut di atas dalam pelaksanaannya harus saling bergantung (bersinergi) satu sama lain, bukan merupakan aktivitas yang berjalan sendiri-sendiri. Aktivitas yang bersinergi tersebut merupakan pelaksanaan dari setiap keputusan yang diambil, dengan demikian manajemen sumber daya manusia (MSDM) pada dasarnya merupakan integrasi keputusan yang membentuk hubungan antar karyawan. Kualitas sinergi mereka memberikan kontribusi terhadap kemampuan SDM dan organisasi dalam mencapai tujuan.

\section{Budaya Tanggungjawab pada Prodi-Prodi di Fakultas Tarbiyah dan Keguruan Dan Fakultas Ushuluddin dan Studi Agama UIN Mataram}

${ }^{23}$ Observasi proses pembelajaran dan pelayanan akademik, tanggal 24 September 2018. 
Lembaga pendidikan tinggi (Perguruan Tinggi) sudah berkembang demikian pesatnya jika dibandingkan dengan puluhan tahun yang lalu. Perguruan Tinggi berkembang dengan berbagai cabang pengetahuan dan kegiatan yang dikelolanya. Sebuah kampus perguruan tinggi sekarang mengelola pegawai dan dosen dengan jumlah yang besar, keuangan, dan kegiatan yang luar biasa padatnya

Atas dasar itulah, maka pengembangan sumber daya manusia merupakan salah satu fungsi operasional manajemen sumber daya manusia (MSDM) yang berisi kegiatan-kegiatan untuk memelihara dan meningkatkan kompetensi pegawai melalui peningkatan pengetahuan, keterampilan, kemampuan dan aspek-aspek lainnya. Pengembangan sumber daya manusia ini penting dilaksanakan disebabkan adanya perubahan baik manusia, teknologi, pekerjaan maupun organisasi. Sumber daya manusia (dosen dan staf) yang memiliki tanggungjawab sangat dibutuhkan oleh lembaga pendidikan untuk berkompetisi dengan lembaga lain, tanggungjawab adalah modal utama bagi berjalannnya kompetisi tersebut.

Sebagaimana terungkap dari hasil wawancara dengan Sekretaris Jurusan Pendidikan Agama Islam FTK, bahwa kualitas layanan akademik di Jurusan PAI berjalan dengan baik. Para dosen mengajar tepat waktu sesuai dengan jadwal yang diberikan, dan layanan konsultasi skripsi dan wali studi berjalan dengan baik, mahasiswa terlayani dengan baik. Demikian pula dengan staf yang ada di jurusan, mereka telah melaksanakan tugas dengan penuh tanggungjawab, memberikan pelayanan sesuai dengan kebutuhan mahasiswa. ${ }^{24}$

Sejalan dengan ungkapan di atas, maka tenaga dosen dan staf harus memiliki kemampuan dalam mengatasi permasalahan terutama berkaitan dengan problematika mahasiswa sebagai bentuk tanggungjawab terhadap keberhasilan mereka. Civitas akademik harus mampu mengarahkan mahasiswa agar lebih aktif dalam belajar. Dengan demikian, kemampuan para tenaga dosen dalam mengelola kegiatan pembelajaran dengan penuh tanggungjawab yang mencerminkan adanya dinamika konstruktif dalam proses pembelajaran, menjadikan mahasiswa memiliki ghirah akademik yang baik.

${ }^{24}$ Wawancara dengan M. Taisir, tanggal 13 Juli 2018. 
Pengembangan sumber daya manusia merupakan salah satu fungsi operasional manajemen sumber daya manusia (MSDM) yang berisi kegiatan-kegiatan untuk memelihara dan meningkatkan kompetensi pegawai melalui peningkatan pengetahuan, keterampilan, kemampuan dan tanggungjawab profesionalitasnya. Pengembangan sumber daya manusia ini penting dilaksanakan disebabkan adanya perubahan baik manusia, teknologi, pekerjaan maupun organisasi.

Strategi pengembangan sumber daya manusia (SDM) harus berawal dari komitmen terhadap visi, misi dan tujuan UIN Mataram, untuk kemudian menyusun desain struktur yang tepat sebagai landasan utama dalam menempatkan orang dalam posisi yang tepat. Hal ini sejalan dengan konsep the right men in the right job at the right time, hal ini menekankan pada pentingnya menempatkan orang pada posisi yang tepat dalam kurun waktu tertentu, sesuai dengan latar belakang keahliannya. Hal demikian dapat menanamkan rasa taggungjawab maksimal dari masing-masing personal yang diberi tanggungjawab, baik untuk melayani mahasiswa di bidang akademik maupun lainnya.

\section{Budaya Keteladanan pada Prodi-Prodi di Fakultas Tarbiyah dan Keguruan Dan Fakultas Ushuluddin dan Studi Agama UIN Mataram}

Pengembangan sumber daya manusia (SDM) dalam hal ini tenaga dosen dan staf memiliki dua pandangan, yaitu normatif dan teknis. Pandangan normatif berkenaan dengan fungsi-fungsi dasar yang harus ada dalam kehidupan manusia dan menjadi patokan ideal untuk pelaksanaan konsep yang lebih implementatif. Sedangkan konsep teknis berkaitan dengan implementasi pandangan normatif dan bersifat kondisional dan kasuistik. Kedua pandangan ini dijadikan dijadikan pendekatan dalam pengkajian awal terhadap pengembangan SDM di UIN Mataram.

FTK dan FUSA adalah dua fakultas yang bernaung di bawah UIN Mataram, secara normatif maupun implementatif harus mencerminkan budaya keteladanan bagi segenap manusia (rahmatan lil alamin). Posisi strategis UIN Mataram memiliki signifikansi yang tinggi dalam mengantisipasi perkembangan yang bergulir dengan cepat, khususnya dalam pemenuhan kebutuhan sumber daya manusia (SDM) yang memiliki kemampuan akademik dan profesional serta berakhlak mulia. Selanjutnya, dapat menghasilkan sumber daya manusia yang mampu menerapkan, 
mengembangkan, menyebarluaskan dan menciptakan ilmu pengetahuan dan seni yang bernafaskan Islam, serta mengupayakan penggunanya untuk meningkatkan taraf kehidupan masyarakat yang bermartabat.

Implikasi dari proses implementasi budaya kerja yang dilakukan secara profesional dapat mendorong adanya pembaruan ide, metode dan strategi untuk mencapai tujuan UIN Mataram dan memecahkan masalah-masalah pendidikan pada umumnya. Inovasi diciptakan untuk pengembangan kreativitas para pelaksana organisasi. Inovasi dilakukan melalui perbaikan, pengembangan, pengayaan, pemodifikasian. Urgensi inovasi dilakukan untuk peningkatan mutu, peningkatan efisiensi, dan efektivitas pendidikan dan relevansi pendidikan.

Fakultas dapat dikatakan bermutu apabila, pertama memiliki prestasi akademik (lebih khusus) menunjukkan pencapaian yang tinggi yaitu perolehan Indeks Prestasi Mahasiswa sesuai standar kelulusan yang telah ditentukan. Kedua, memiliki nilai-nilai kejujuran, ketaqwaaan, kesopanan dan mampu mengapresiasi nilai-nilai budaya. Ketiga, memiliki tanggung jawab yang tinggi dan kemampuan yang diwujudkan dalam bentuk keterampilan sesuai dengan dasar ilmu yang diterimanya di kampus.

Dimensi lain dari adanya sikap keteladanan yang harus dimiliki dalam kaiatannya dengan kegiatan layanan akademik adalah membimbing dan memberikan arahan kepada setiap mahasiswa yang memiliki perilaku kurang baik dengan tutur kata yang dapat menggugah perasaan mereka. Pentingnya pola ini dilakukan agar mahasiswa tidak merasa terpaksa melaksanakan setiap perintah dan anjuran yang diberikan oleh para dosen. Perubahan sikap akan menjadi fenomena yang alamiah dari para mahasiswa, ketika mereka menyaksikan seluruh civitas akademik memiiki sikap yang dapat diteladani oleh semua pihak (qudwah hasanah). Dosen dan staf akan menjadi teladan dalam mewujudkan perubahan sikap para mahasiswa.

\section{Kesimpulan}

1. Budaya integritas pada Prodi-Prodi di Fakultas Tarbiyah dan Keguruan Dan Fakultas Ushuluddin dan Studi Agama UIN Mataram adalah

a. Keselarasan antara hati, pikiran, perkataan, dan perbuatan yang baik dan benar, 

b. Bertekad dan berkemauan untuk berbuat yang baik dan benar,
c. Berpikir positif, arif, dan bijaksana dalam melaksanakan tugas dan fungsi,
d. mematuhi peraturan perundang-undangan, dan
e. menolak korupsi, suap atau gratifikasi

2. Budaya profesionalitas pada Prodi-Prodi di Fakultas Tarbiyah dan Keguruan Dan Fakultas Ushuluddin dan Studi Agama UIN Mataram adalah
a. Bekerja secara disiplin, kompeten dan tepat waktu dengan hasil terbaik,
b. Melakukan pekerjaan sesuai kompetensi jabatan,
c. Disiplin dan bersungguh-sungguh dalam bekerja,
d. Melakukan pekerjaan secara terukur,
e. Melaksanakan dan menyelesaikan tanggung jawab tepat waktu dan
f. Menerima reward dan punishment sesuai dengan ketentuan

3. Budaya inovasi pada Prodi-Prodi di Fakultas Tarbiyah dan Keguruan Dan Fakultas Ushuluddin dan Studi Agama UIN Mataram adalah
a. Menyempurnakan yang sudah ada dan mengkreasi hal baru yang lebih baik
b. Selalu melakukan penyempurnaan dan perbaikan berkala dan berkelanjutan
c. Bersikap terbuka dalam menerima ide-ide baru yang konstruktif
d. Meningkatkan kompetensi dan kapasitas pribadi
e. Berani mengambil terobosan dan solusi dalam memecahkan masalah
f. Memanfaatkan teknologi informasi dan komunikasi dalam bekerja secara efektif dan efesien

4. Budaya tanggung jawab pada Prodi-Prodi di Fakultas Tarbiyah dan Keguruan Dan Fakultas Ushuluddin dan Studi Agama UIN Mataram
a. Bekerja secara tuntas dan konsekuen
b. Menyelesaikan pekerjaan dengan baik dan tepat waktu
c. Berani mengakui kesalahan, bersedia menerima konsekuensi dan melakukan langkah-langkah perbaikan
d. Mengatasi masalah dengan segera
e. Komitmen dengan tugas yang diberikan

5. Budaya keteladanan pada Prodi-Prodi di Fakultas Tarbiyah dan Keguruan Dan Fakultas Ushuluddin dan Studi Agama UIN Mataram 

a. Menjadi contoh yang baik bagi orang lain
b. Ahlak terpuji
c. Pelayanan dengan sikap yang baik, penuh keramahan dan adil
d. Membimbing dan memberikan arahan kepada bawahan dan teman sejawat
e. Melakukan pekerjaan yang baik di muali dengan diri sendiri

\section{Daftar Pustaka}

A. Miller dan G. Dess, G. Strategic Manjemen, New York: McRaw Hill Companies, 1996.

Abbas, Syahrizal. Manajemen Perguruan Tinggi.

Andi Eko P. Pengarub Budaya Kerja Terbadap Perilaku Kerja dan Kinerja Karyawan Pada PT. BANK Pembangunan Daerah Bayuwangi, Skripsi, Fakultas Ekonomi Universitas Jember, 2011

Anhar, Budaya Kerja Kementrian Agama, Jakarta: Kementrian Agama RI, 2015.

Arif, Mahmud. Pendidikan Islakm Transformatif,

Yogyakarta: Elkis Yogyakarta, 2008.

Bandung, 1994.

Bodgan, Robert dan Steven J. Tailor, Dasar-Dasar Penelitian Kualitatif,

Dedi, Supriadi. Kreativitas, kebudayaan, dan Perkembangan Iptek. Bandung: Alfabeta, 2009.

Engkoswara, Dasar-Dasar Administrasi Negara, Jakarta: P2LPTK, 1987. Gaffar, M. Fakry. Pengelolaan Pendidikan, Bandung: tim Dosen FIP IKIP

Idrus, Ali. Manajemen Pendidikan Global.

Kasiram, Moh. Penelitian Pendidikan dalam Perspektif Pemberdayaan Sumberdaya Manusia.

Pidato Pengukuhan Guru Besar Bidang Penelitian pada Sekolah Tinggi Agama Islam Negeri Malang pada tanggal 3 April 1999.

Kemenag, Pedoman Budaya Kerja, Jakarta: Kemenag, 2015. Koncoro, E. A.. Leadership. Bandung: PT. Alfabeta, 2009.

Rusdiana dan yeti Hermayati, Pendidikan Profesi Keguruan, Bandung : Pustaka Setia, 2015.

Sabila, Lubis. Pengarub Budaya Kerja dan sikap inovatif terhadap Kinerja Guru MAN, skripsi, Fakultas Ekonomi Universitas Medan, 2012. 
Budaya Integritas Pada Prodi-Prodi di Fakultas Tarbiyah dan Keguruan dan Fakultas Ushuluddin dan Studi Agama UIN Mataram

Sandra L. Johnson dan Sean C. Rush, Reinventing The University.

Supriyadi, Gering dan Tri Guno, Budaya Kerja Organisasi Pemerintah, Jakarta: Lembaga Administrasi Negara, 2003.

Surabaya: Usaha Nasional, 1993.

Tilaar, H. A. R. Paradigma baru Pendidikan nasional, Jakarta: Rineka cipta, 2000. 